\title{
1 The influence of environmental setting on the community ecology of Ediacaran organisms
}

2

3 Emily G. Mitchell ${ }^{1}$, Nikolai Bobkov ${ }^{2,3}$, Natalia Bykova ${ }^{2,4}$, Alavya Dhungana, , , Anton

4 Kolesnikov ${ }^{2,6,7}$, Ian R. P. Hogarth ${ }^{8,9}$ Alexander G. Liu $^{10}$, Tom M.R. Mustill ${ }^{10,11}$, Nikita

5 Sozonov $^{2,3}$, Shuhai Xiao ${ }^{4}$ and Dmitriy V. Grazhdankin ${ }^{2,3}$.

6

7

8

$9{ }^{1}$ Department of Zoology, University of Cambridge, UK.

$10 \quad{ }^{2}$ Institute of Petroleum Geology and Geophysics, Novosibirsk, Russian Federation.

$11{ }^{3}$ Novosibirsk State University, Russian Federation.

$12{ }^{4}$ Department of Geosciences, Virginia Tech, Blacksburg, VA 24061, United States.

$13 \quad{ }^{5}$ Department of Earth Sciences, Durham University, UK.

$14{ }^{6}$ Geological Institute, Russian Academy of Sciences, Moscow, Russian Federation.

$15{ }^{7}$ Department of Geography, Moscow Pedagogical State University, Moscow, Russian 16 Federation.

$17{ }^{8}$ Department of Chemical Engineering, University of Cambridge, UK.

$18{ }^{9}$ Current address: University College London, UCL Institute for Innovation and Public

19 Purpose, UK.

$20{ }^{10}$ Department of Earth Sciences, University of Cambridge, UK.

$21{ }^{11}$ Current address: Gripping Films, St. John's Church Road, London, England, E9 6EJ. 


\section{Abstract}

26 The broad-scale environment plays a substantial role in shaping modern marine ecosystems,

27 but the degree to which palaeocommunities were influenced by their environment is unclear.

28 To investigate how broad-scale environment influenced the community ecology of early

29 animal ecosystems we employed spatial point process analyses to examine the community

30 structure of seven bedding-plane assemblages of late Ediacaran age (558-550 Ma), drawn from a range of environmental settings and global localities. The studied palaeocommunities exhibit marked differences in the response of their component taxa to sub-metre-scale habitat heterogeneities on the seafloor. Shallow-marine palaeocommunities were heavily influenced by local habitat heterogeneities, in contrast to their deep-water counterparts. Lower species richness in deep-water Ediacaran assemblages compared to shallow-water counterparts across the studied time-interval could have been driven by this environmental patchiness, because habitat heterogeneities correspond to higher diversity in modern marine environments. The presence of grazers and detritivores within shallow-water communities may have promoted local patchiness, potentially initiating a chain of increasing heterogeneity of benthic communities from shallow to deep-marine depositional environments. Our results provide quantitative support for the "Savannah" hypothesis for early animal diversification - whereby Ediacaran diversification was driven by patchiness in the local benthic environment.

\section{Keywords}

45 Ediacaran, palaeoecology, spatial analysis, early animal diversification.

\section{Author Contributions}

47 E. Mitchell conceived this paper and wrote the first draft. N. Bobkov, A. Kolesnikov, N.

48 Sozonov and D. Grazhdankin collected the data for DS surface. N. Bobkov and N. Sozonov performed the analyses on DS surface. N. Bykova, S. Xiao, and D. Grazhdankin collected the 
data for WS, KH1 and KH2 surfaces and E. Mitchell performed the analyses. A. Dhungana and A. Liu collected the data for FUN4 and FUN5 surfaces and A. Dhungana performed the analyses. T. Mustill and D. Grazhdankin collected the data for KS and T. Mustill and E. Mitchell performed the analyses. I. Hogarth developed the software for preliminary KS surface analyses. E. Mitchell, N. Bobkov, N. Bykova, A. Dhungana, A. Kolesnikov, A. Liu, S. Xiao and D. Grazhdankin discussed the results and prepared the manuscript.

\section{Background}

The Ediacaran-Cambrian transition $(\sim 580-520$ million years ago) is one of the most remarkable intervals in the history of life on Earth, witnessing the rise of large, complex animals in the global oceans $(1,2)$. The diversification of early animals coincides with dramatic perturbations in the global abiotic environment, including changes to carbon cycling and a progressive but dynamic oxygenation of the oceans $(3,4)$. The extent to which animals themselves drove these global changes is a matter of considerable debate (5-7) with several competing hypotheses suggested to explain their observed diversification. These include global abiotic changes that occured over kilometre scales $(8,9)$ and biotic factors acting over local scales (metre to kilometre), and include organism interactions such as burrowing and/or predation $(10,11)$. Feedbacks between biotic and abiotic factors have also been proposed as drivers of early animal diversification, whereby Ediacaran organisms directly or indirectly created patchy food resources, stimulating the evolution of mobile bilaterians $(12,13)$. Due to the small (within community) spatial scales over which key evolutionary mechanisms often act (14), investigation of the community ecology of Ediacaran assemblages over broad (kilometre) spatial scales offers an opportunity to link the interactions of individual organisms to macroevolutionary and macro-ecological trends. In this study, we investigate the relationship between late Ediacaran early animal diversification and the broad-scale environment. 
76 Ediacaran macrofossils occur globally across a wide-range of palaeo-environments (1).

77 Previous studies have separated late Ediacaran palaeocommunities into three taxonomically distinct assemblages - the Avalon, White Sea and Nama - which occupy partially overlapping temporal intervals and different water-depths with no significant litho-taphonomic or biogeographic influence (15-17). This study focusses on palaeocommunities within the Avalon and White Sea fossil assemblages that are considered to reflect original in situ communities $(18,19)$, permitting the use of statistical analyses of the distribution of fossil specimens on bedding planes (spatial point process analyses, SPPA) to reconstruct the interaction of organisms with each other and their local environment (20-25). The Avalon assemblage is primarily represented by sites in Newfoundland, Canada and Charnwood Forest UK $(26,27)$, and typically documents mid-shelf/deep-water settings (from depths below the edge of the continental shelf - the slope break) of 575-566 Ma (28,29). Such sites exhibit relatively limited ecological and morphological diversity (30,31), and palaeocommunities consisting almost exclusively of sessile taxa (32) that show only weak trends with community

90 composition along regional palaeoenvironment gradients (20). Previous spatial analyses of

91 Avalonian communities have found limited evidence for environmental interactions within 92 these communities (21-23), in contrast to the strong imprint exerted by resource-limitation on modern deep-sea ecosystems $(33,34)$.

94 Palaeocommunities from the White Sea assemblage are most famously represented by sites in 95 South Australia, and the East European Platform of Russia, dating to 558-555 Ma (35-37).

96 These assemblages typically document shallow-water, diverse communities including taxa 97 interpreted as bilaterians (38), herbivores (39), detritivores (40) and motile organisms (41).

98 Within the White Sea assemblages, community composition is strongly correlated with 
sedimentary environment and the presence of textured organic surfaces at bed-scale level $(42,43)$.

101

102 Metrics of taxonomic and ecological diversity are much higher in White Sea assemblages than 103 in Avalonian ones, with changes in taxonomic and morphological diversity calculated to be of 104 similar magnitude to those between the Ediacaran and Cambrian (30,31). These Ediacaran assemblages have high beta-diversity compared to modern benthic systems (44), but the driving processes underlying this high diversity are not understood. The regional

107 palaeoenvironment (kilometre scale) $(15,17)$ has a significant influence on (non-algal 108 dominated) Ediacaran fossil assemblage composition, but metreits influence on local (metre to 109 sub-metre scale) community ecology has not yet been investigated. In modern benthic 110 communities, small spatial scale $(<50 \mathrm{~cm})$ substrate heterogeneities (e.g. substrate variations

111 in nutrients, oxygen patchiness, or biotic and abiotic gradients within microbial mats) exert a

112 significant influence on community ecology $(33,34,45)$. For Ediacaran palaeocommunities, it

113 is not possible from spatial analyses alone to determine the underlying causes of habitat

114 heterogeneities, nor the extent to which they relate to food resources, such as those resulting

115 from the decay of Ediacaran organisms $(12,46)$. However, it is possible to compare how the

116 relative influence of such heterogeneities changes with broad-scale environmental setting:

117 previous analyses have identified assemblage-level trends between community compositions

118 and bathymetric depth (15-17). In this study, we compare the drivers of community ecology

119 between shallow and deep-water Ediacaran palaeocommunities (above or below the slope 120 break) over a 7-million-year period using spatial analyses of seven palaeocommunities.

\section{Spatial analyses}


123 Determining the nature of interactions between fossilised organisms and their environment can

124 be undertaken if entire palaeocommunities are preserved in-situ, such that the position of the

125 fossils on bedding planes can be interpreted to reflect aspects of the organism's life-history

126 (47). For sessile organisms, such as in the Avalon communities, community-scale spatial

127 distributions are dependent upon the interplay of a limited number of factors: physical

128 environment (which manifests as habitat associations of a taxon or taxon-pairs (48)); organism

129 dispersal/reproduction (49); competition for resources (50); facilitation between taxa (where

130 one taxon increases the survival another taxa) (51); and differential mortality (52). For fossil

131 assemblages containing mobile taxa (e.g. the White Sea assemblages), behavioural ecology

132 also influences spatial distributions, so interpretations of their spatial distributions are

133 qualitative rather than quantitative.

135 Studies of modern ecosystems have demonstrated that habitat associations resulting from

136 interactions between organisms and their local environment can be either positive, leading to

137 aggregations of individuals (such as around a preferential substrate for establishment), or

138 negative segregation away from such patches (21). SPPA are a suite of analyses compare the

139 relative density of points (in this case fossil specimens) to different models corresponding to

140 different ecological processes, in order to infer the most likely underlying process responsible

141 for producing the observed spatial distribution. For sessile organisms, habitat associations

142 identified by SPPA are best-modelled by a heterogeneous Poisson model (HP), or when

143 combined with dispersal limitations, an Inhomogeneous Thomas Cluster model (ITC) $(53,54)$.

144 Where the local environment is resource-limited to the extent that it significantly reduces

145 organism densities, this is indicated by spatial segregation between specimens within a

146 community (55). When sessile populations are not significantly affected by their local

147 environment, their spatial distributions are completely spatially random (CSR), indicating no 
148 significant influence by any biological or ecological processes at the spatial scale investigated,

149 or alternatively reflect dispersal/reproductive processes $(48,54,56-58)$. CSR is modelled by

150 homogeneous Poisson processes (47), whereas dispersal patterns are best modelled by best-fit

151 Thomas Cluster (TC) or Double Thomas Cluster (DTC) models (54). Facilitation (where one

152 taxa increases the survival of another) is best-modelled by linked-cluster models $(51,59)$ and

153 density-dependent processes detected using random-labeling analyses $(52,60)$.

\section{Geological setting}

156 We assessed the community palaeoecology of seven fossil-bearing assemblages across five 157 different global Ediacaran locations, spanning the full range of known habitats inhabited by members of the Ediacaran macrobiota during the late Ediacaran interval, and incorporated data

159 from previous studies $(21,23)$ on Avalonian palaeocommunities for comparison. These

160 localities document a range of diverse local depositional environments, but in order to focus 161 on the broadest macro-ecological and macro-evolutionary patterns we have coarsely grouped them within either shallow or deep-water settings.

\section{Shallow marine settings}

165 Five of the studied palaeocommunities are found in facies that reflect shallow marine depositional

166 environments. Palaeocommunity WS is an Aspidella-bearing surface on the underside of a wave-

167 rippled sandstone within a thick package of mudstones and sandstones deposited in a prograding,

168 storm-influenced depositional system $(61,62)$. It was collected from the Lyamtsa Formation of the

169 Valdai Group, along the Onega Coast of the White Sea, Russian Federation, and remained in the field

170 where it was destroyed by landslides. Aspidella specimens were collected and are stored uncatalogued

171 at the Trofimuk Institute for Petroleum Geology and Geophysics in Novosibirsk. The Lyamtsa

172 Formation is older than a date of $558 \pm 1 \mathrm{Ma}(\mathrm{U} / \mathrm{Pb}$ zircon dating of volcanic tuffs near the base of the 
173 overlying Verkhovka Formation) (16). Surface (KS) is on the lower surface of a finely laminated

174 sandstone, interpreted as a flood deposit within a prograding prodelta depositional system (63). This

175 surface, within the lower member of the Erga Formation (Winter Coast of the White Sea) $(16,35)$,

176 contains the fossil Kimberella, and is younger than $552.85 \pm 0.77 \mathrm{Ma}(64)$ (date recalculated from

177 Martin et al. (65)). The KS surface remained in the field and has been subsequently destroyed by land

178 slides and weathering. Two Funisia-bearing surfaces from the base of thin-bedded wave-rippled

179 quartz sandstones representing deposition in prodelta marine settings between fair-weather and storm

180 wave base originate from the Ediacara Member of South Australia $(42,66-68)$. These surfaces reside

181 in the collections of the South Australia Museum, with surface FUN4 collected from Ediacara

182 Conservation Park (SAM P55236) and surface FUN5 collected from the Mount Scott Range (SAM

183 P41506). Since FUN4 and FUN5 originate from different localities (> $50 \mathrm{~km}$ apart), is it assumed

184 likely that they represent discrete bedding plane/palaeocommunities. The South Australian Ediacaran successions have not been radiometrically dated, but the Ediacara Member is widely assumed to be of a similar age to the White Sea fossil-bearing sections $(1,2)$.

187

188 Surface DS is a Dickinsonia-bearing surface from the Konovalovka Member of the Cherny

189 Kamen Formation, cropping out along the Sylvitsa River, Central Urals, Russia $(63,69)$. It

190 lies within an interval of finely alternating wave-rippled sandstones, siltstones and mudstones

191 that are sandwiched between two thick intervals of biolaminated sandstone characterised by

192 microbial shrinkage cracks and salt crystal pseudomorphs (70). The overall succession is

193 considered transitional from marginal marine to non-marine, with the fossil-bearing interval

194 interpreted as having been deposited in a lagoon within a tidal flat depositional system (70).

$195 \mathrm{~A} \mathrm{U} / \mathrm{Pb}$ zircon date of $557 \pm 13 \mathrm{Ma}$ from volcanic tuffs near the base of the Cherny Kamen

196 Formation (63) suggests that this unit may have been deposited broadly coevally with those

197 on the White Sea coast. Specimens from this surface reside in Novosibirsk State University, 
198 Russian Federation (specimen numbers: 2057-001 to 2057-003) and will be placed at the Ural

199 Geological Museum (Yekaterinburg).

200

201 All five of these surfaces therefore represent siliciclastic depositional environments from

202 above the slope break, and so fall broadly into the grouping of "shallow marine". They

203 contain examples of taxa interpreted as animals (e.g. Dickinsonia, Kimberella) as well as non-metazoans (Orbisiana) and their age and facies place them within the White Sea assemblage $(15,17)$.

Deep-water marine setting

208 Two bedding surfaces dominated by Aspidella specimens (KH1 and KH2) were collected from a package of finely alternating limestone and shale interbeds within the Khatyspyt

210 Formation, Olenek River, Siberia. Sedimentological observations (e.g., turbiditic nature of

211 the limestones; evidence of strong unidirectional flows; intraclasts originating from outside of

212 the Khatyspyt depositional basin) suggest the Khatyspyt Formation was deposited within a

213 starved intracratonic rift basin developed in a marine ramp setting within a relatively deepwater setting beyond the shelf slope break (71-74). A positive $\delta^{13} \mathrm{C}_{\text {carb }}$ excursion in the

215 Khatyspyt Formation has been correlated with an excursion of similar magnitude in the $<550$

216 Ma Gaojiashan Member of the Dengying Formation (74). Strontium isotope ratios $\left({ }^{87} \mathrm{Sr} /{ }^{86} \mathrm{Sr}\right)$

217 in the Khatyspyt Formation are consistently ca. $0.7080(74,75)$, a value approaching some of

218 the ratios seen in the Gaojiashan Member (76), so this correlation seems plausible. Surface

219 KH2 remains in the field and surface KH1 was destroyed while excavated KH. Specimens

220 from KH1 surface reside in Trofimuk Institute for Petroleum Geology and Geophysics,

221 collection number 913 (specimen numbers: 0607/2009-3, 0607/2009-6, 0607/2009-7,

$2220607 / 2009-17,0607 / 2009-18)$. 

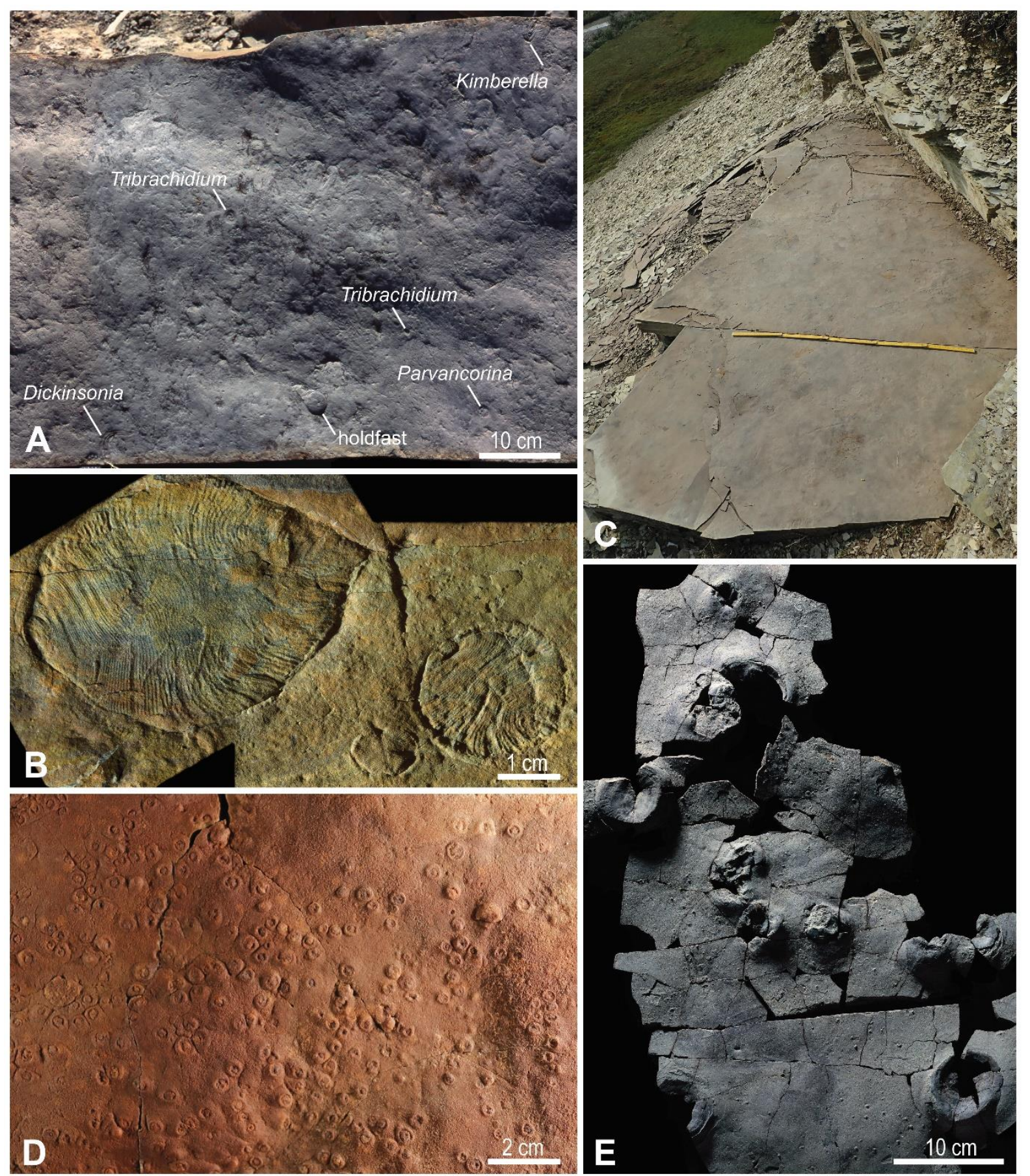

E

$10 \mathrm{~cm}$

226 Fig. 1. Assemblages of Ediacaran fossils from study localities. A) A fragment of the

227 Kimberella surface (KS), indicating key taxa, lower Erga Formation, Winter Coast of the White

228 Sea. B) Specimens of Dickinsonia from the Dickinsonia surface (DS), Konovalovka Member,

229 Cherny Kamen Formation, Sylvitsa River, Central Urals. C) The Aspidella surface (KH1), 
230 Khatyspyt Formation, Olenek Uplift, Northern Siberia. Metre rule for scale. D) Funisia from

231 FUN4 surface (SAM P55236), Ediacara Member, Rawnsley Quartzite, South Ediacara, Flinders

232 Range, South Australia. E) A representative fragment of the WS surface, upper Lyamtsa

233 Formation, White Sea Region. This particular fragment was not included in the analysis. These

234 data were compared with 7 palaeocommunities that have been subjected to SPPA in previous

235 studies $(21,23)$, where details of data collection and locality information are described.

236

\section{Data Collection}

238 Spatial data were collected from the surfaces using different methods depending on the 239 physical properties of the bedding plane. The WS, KH1, KH2 surfaces were mapped in the 240 field (WS in 2017, KH1 in 2006 and 2009, and KH2 in 2018) onto millimetre graph paper.

241 First, the co-ordinates of the edge of the rock surface were recorded, then the co-ordinates,

242 orientation and dimensions of each of the specimen were measured and plotted onto the paper.

243 For DS, a bedding surface of $9 \mathrm{~m}^{2}$ was excavated over the course of two years (2017-2018).

244 The surface was photo-mapped, with photographs taken under an artificial light source at night.

245 The intersection between maximum length (L) and maximum width (W) of each specimen was 246 taken to be the absolute position of the organism, with measurements obtained from digital

247 photographs using Adobe Photoshop CC software and Apple Script Editor.

248

\begin{tabular}{l|lcccc}
\hline Surface & $\begin{array}{c}\text { Environmental } \\
\text { setting }\end{array}$ & $\begin{array}{c}\text { Species } \\
\text { richness }\end{array}$ & Dominant Taxa & $\begin{array}{c}\text { Specimen } \\
\text { numbers }\end{array}$ & $\begin{array}{c}\text { Area mapped } \\
\left(\mathbf{m}^{2}\right)\end{array}$ \\
\hline$W S$ & Shallow & 1 & Aspidella & 40 & 0.54 \\
$K H 1$ & Deep & 2 & Aspidella & 204 & 2.38 \\
$K H 2$ & Deep & 2 & Aspidella & 81 & 1.52 \\
$D S$ & Shallow & 1 & Dickinsonia & 62 & 9.00 \\
$K S$ & Shallow & 13 & Kimberella, Orbisiana & 107 & 2.74 \\
$F U N 4$ & Shallow & 2 & Funisia & 290 & 0.69 \\
FUN5 & Shallow & 1 & Funisia & 482 & 0.78 \\
\hline
\end{tabular}


250 Table 1. Summary data of the surfaces mapped. The environmental setting, species richness, specimen numbers within the mapped area, and the total mapped area are provided.

The KS surface was excavated in July 2004, and is a laterally discontinuous transect consisting of four slabs of variable size, ranging from $0.6 \times 0.4 \mathrm{~m}$ to $1.6 \times 1.0 \mathrm{~m}$. The relative positions of the slabs within the transect were mapped in situ on an excavated terrace. A separate block originating from the same horizon was found in float close to the transect. Following reassembly, the taxonomic identity, positions, orientations and shapes of the fossils were mapped at millimetre scale. For the FUN4 and FUN5 surfaces, photogrammetric maps of the bedding surfaces were made, with lens edge effects corrected using RawTherapee (v. 2.4.1).

260 For all mapped palaeocommunities, fossil identification, position, and dimensions (disc width, 261 disc length, stem length, stem width, frond length, and frond width) were digitized in Inkscape 0.92.3 on a $2 \mathrm{D}$ projection of the dataset, resulting in a $2 \mathrm{D}$ vector map for each palaeocommunity. Only taxa that had sufficient abundance (> 5 specimens) for spatial analyses

264 were formally identified, and these were grouped within one of six taxonomic groups:

265 Aspidella, Dickinsonia, Funisia, Kimberella, Orbisiana, and the trace fossil Kimberichnus. A group consisting of all the sessile taxa on the KS surface was also assessed, because abundance was not sufficient to include all taxa individually. Analyses were not conducted for individual low abundance taxa whose specimen numbers fell below the threshold for which results would be statistically meaningful. 


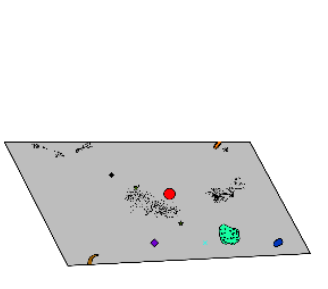

$-$
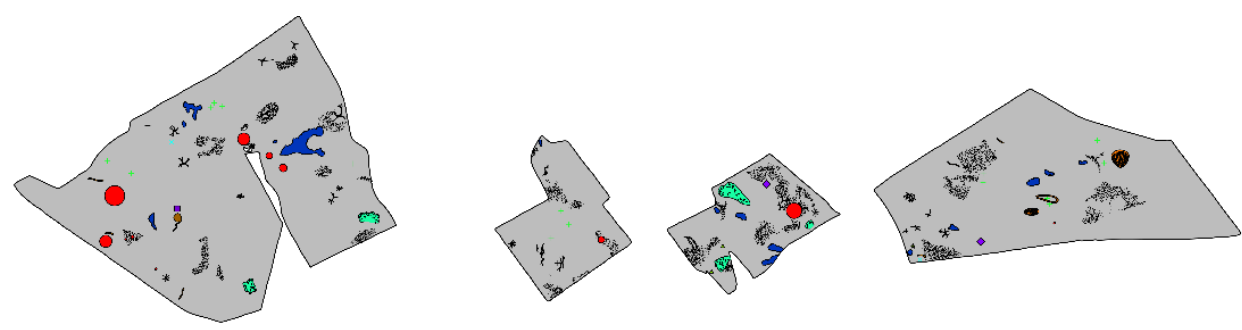

KS Surface, White Sea

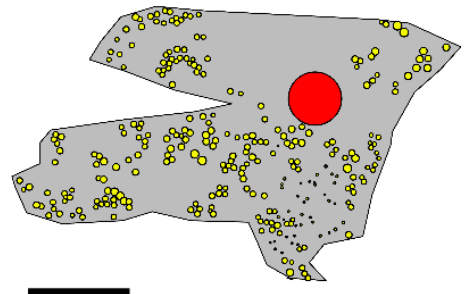

FUN4, Ediacara

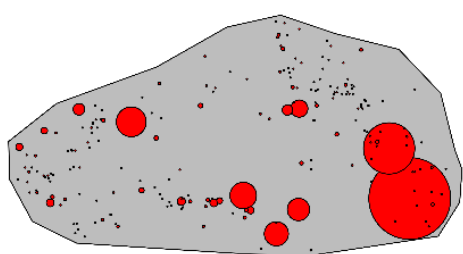

KH1 Surface, Olenek Uplift

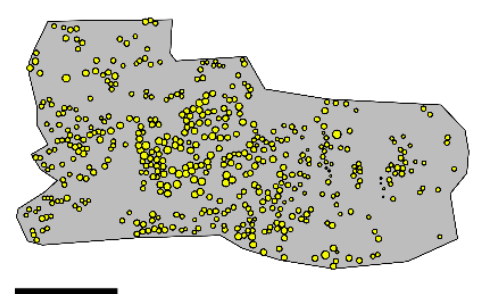

FUN5, Ediacara

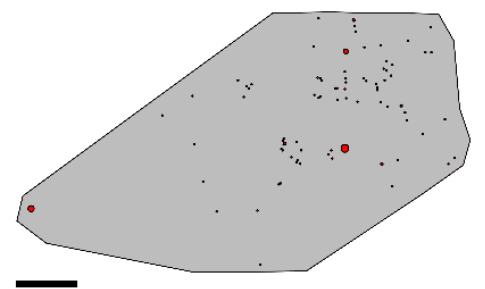

KH2 Surface, Olenek Uplift

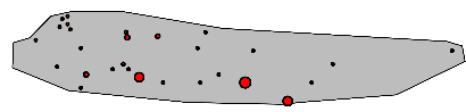

WS, White Sea

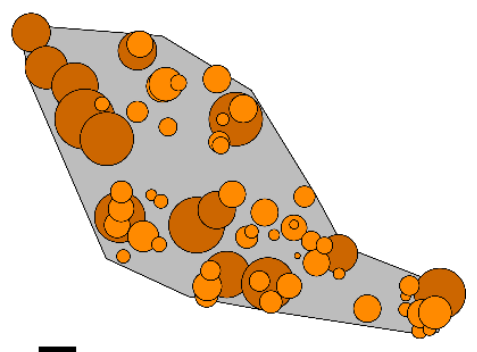

DS Surface, Urals

273 Fig 2. Spatial maps of the seven studied palaeocommunities. Scale bar is $10 \mathrm{~cm}$. Different colours indicate different taxa as follows: Red, Aspidella; Orange, Dickinsonia; Yellow circles, Funisia; Light green scratch marks, Kimberichnus; Light green crosses, Kimberella; Blue crosses, Charniodiscus; Green triangles, Parvancorina; Dark blue patches, Orbisiana; Black stipples, horizontal traces; White globular strings, Palaeopasichnus; Purple diamonds, Andiva; Purple squares, Yorgia. Size of the circles corresponds to specimen length or diameter (as appropriate). On the DS surface, dark orange circles are the large size-class of Dickinsonia, and the light orange represents the small size-class. 


\section{Methods}

\section{Bias analyses}

286 For each surface, we first tested for erosional biases and tectonic deformation, since both have

287 the potential to distort spatial analyses $(18,73)$. If these factors were found to have significantly

288 affected specimen density distributions, the erosion and/or deformation were taken into account when performing later analyses (cf. (23)), with heavily eroded sections of the bedding planes excluded from analyses. The influence of tectonic deformation was only observed on the DS surface, so retrodeformation techniques $(18,25)$ were not applied to the spatial maps of WS, KH1, KH2, KS, FUN4 and FUN5 surfaces. Where possible (WS, KH1 and KH2 surfaces), the area near the outcrops was investigated, and no independent evidence for tectonic deformation was found. The holdfast discs on surfaces KS, FUN4 and FUN5 did not show any evidence tectonic deformation. The DS surface showed signs of deformation in the form of consistent variation in specimen length to width ratios along a presumed axis of deformation. The fitModel function from the mosaic package in $\mathrm{R}(73)$ was used to find the best-fit values

298 for the direction and strength of deformation using the assumption that Dickinsonia had a consistent length to width ratio during the ontogeny $(43,77,78)$ though note $(79))$, and the spatial map was retrodeformed cf. $(18,23,25)$.

301

\section{Spatial Analyses}

303 Initial data exploration, inhomogeneous Poisson modelling, and segregation tests were

304 performed in $\mathrm{R}(75)$ using the package spatstat $(80,81)$. Programita was used to obtain

305 distance measurements and to perform aggregation model fitting (described in detail in

306 references $(48,52,80,82-86)$. 
308 Univariate and bivariate pair correlation functions (PCFs) were calculated from assemblage

309 population densities using a grid of $1 \mathrm{~cm} \times 1 \mathrm{~cm}$ cells on all surfaces except DS, where a 10

$310 \mathrm{~cm} \times 10 \mathrm{~cm}$ cell size was used to correspond to the larger overall mapped area. To minimise

311 noise, a 3 cell smoothing was calculated dependent on specimen abundance, which was

312 applied to the PCF (59). To test whether the PCF exhibited complete spatial randomness

313 (CSR), 999 simulations were run for each univariate and bivariate distribution, with the 49

314 highest and $49^{\text {th }}$ lowest values removed (59). CSR was modelled by a Poisson model on a

315 homogeneous background where the PCF $=1$ and the fit of the fossil data to CSR was

316 assessed using Diggle's goodness-of-fit test $(56,87)$. Note that due to non-independence of

317 spatial data, Monte-Carlo generated simulation envelopes cannot be interpreted as confidence

318 intervals. If the observed data fell below the Monte-Carlo simulations, the bivariate

319 distribution was interpreted to be segregated; above the Monte-Carlo simulations, the

320 bivariate distribution was interpreted to be aggregated $(47,59)$.

321

322 If a taxon was not randomly distributed on a homogeneous background, and was aggregated,

323 the random model on a heterogeneous background was tested by creating a heterogeneous

324 background from the density map of the taxon under consideration. This density map was

325 defined by a circle of radius $\mathrm{R}$ over which the density was averaged throughout the sample

326 area. Density maps were formed using estimators within the range of $0.1 \mathrm{~m}<R<1 \mathrm{~m}$, with

$327 R$ corresponding to the best-fit model used. If excursions outside the simulation envelopes

328 for both homogeneous and heterogeneous Poisson models remained, then Thomas cluster

329 models were fitted to the data as follows: 
331 1. The PCF and L-function (88) of the observed data were found. Both measures were

332 calculated to ensure that the best-fit model is not optimized towards only one distance

333 measure, and thus encapsulates all spatial characteristics.

334 2. Best-fit Thomas cluster processes (89) were fitted to the two functions where PCF > 1.

335 The best-fit lines were not fitted to fluctuations around the random line of PCF $=1$ in order

336 to aid good fit about the actual aggregations, and to limit fitting of the model about random

337 fluctuations. Programita used the minimal contrast method $(56,87)$ to find the best-fit model.

338 3. If the model did not describe the observed data well, the lines were re-fitted using just the

339 PCF. If that fit was also poor, then only the L-function was used.

340 4. 99 simulations of this model were generated to create simulation envelopes, and the fit

341 checked using the O-ring statistic (82).

342 5. In order to assess how well the model fit the observed data, the goodness-of-fit $\left(p_{d}\right)$ was

343 calculated over the model range (86). A $p_{d}=0$ indicates no model fit, and $p_{d}=1$ indicates a

344 perfect model fit. Very small-scale segregations (of the order of specimen diameter) were not

345 included in the model fitting, since they likely represent the finite size of the specimens, and

346 a lack of specimen overlap.

347 6. If there were no excursions outside the simulation envelope and the $p_{d}$-value was high,

348 then a univariate homogeneous Thomas cluster model was interpreted as the best model.

350 For any univariate distributions exhibiting CSR, the size-classes of each taxon were

351 calculated, the univariate PCFs of the smallest size-classes and largest size-classes were

352 plotted, with 999 Monte Carlo simulations of a complete spatially random distribution and

353 segregation tests performed. The most objective way to resolve the number and range of size

354 classes in a population is by fitting height-frequency distribution data to various models,

355 followed by comparison of (logarithmically scaled) Bayesian information criterion (BIC) 
values (86), which we performed in R using the package MCLUST (90). The number of

models are the same, whereas values $<6$ indicate only weakly rejected similarity of the models (90-94). Once defined, the PCFs for each size class were calculated.

Bivariate analyses were performed on the KS surface (the only surface with multiple abundant taxa/taxon groups) between Kimberella - Orbisiana, Kimberella - Kimberichnus and Orbisiana-Kimberichnus. For each taxon pair, the bivariate PCF was calculated, and then compared to CSR using Monte Carlo simulations and Diggle's goodness-of-fit test.

\section{Results}

Across the seven palaeocommunities, Dickinsonia on the DS surface was the only taxon that exhibited CSR. There were five univariate distributions (Sessile Taxa on KS, Funisia on FUN4 and FUN5, Aspidella on $\mathrm{KH} 1$ and $\mathrm{KH} 2$ ) exhibiting aggregated spatial distributions, two univariate (Aspidella on WS and large Dickinsonia on DS) and one bivariate (Kimberella and aggregations from $\mathrm{KH} 1$ and $\mathrm{KH} 2$ were best modelled by the same double Thomas cluster process $\left(p_{d}{ }^{k h 1}=0.883, p_{d}{ }^{k 21}=0.932\right.$, Fig. 3G, H; Table 2), which consisted of large clusters of $20.96 \mathrm{~cm}$ diameter containing smaller clusters with a mean of six specimens within a cluster distributions were most likely due to two generations of reproduction cf. (47), and do not represent a significant interaction or association with local habitat variations. This result is consistent with previous work on older ( 565 Ma) deep-water communities that also show a strong non-environmentally influenced signal (23). In contrast, the Aspidella from the WS 

in a resource-limited environment (55). Funisia from FUN4 and FUN5 had aggregations that are best-modelled by heterogeneous Poisson processes $\left(p_{d}{ }^{F u n 4}=0.9570, p_{d}{ }^{F u n} 5=0.9080\right.$, Fig . environment.
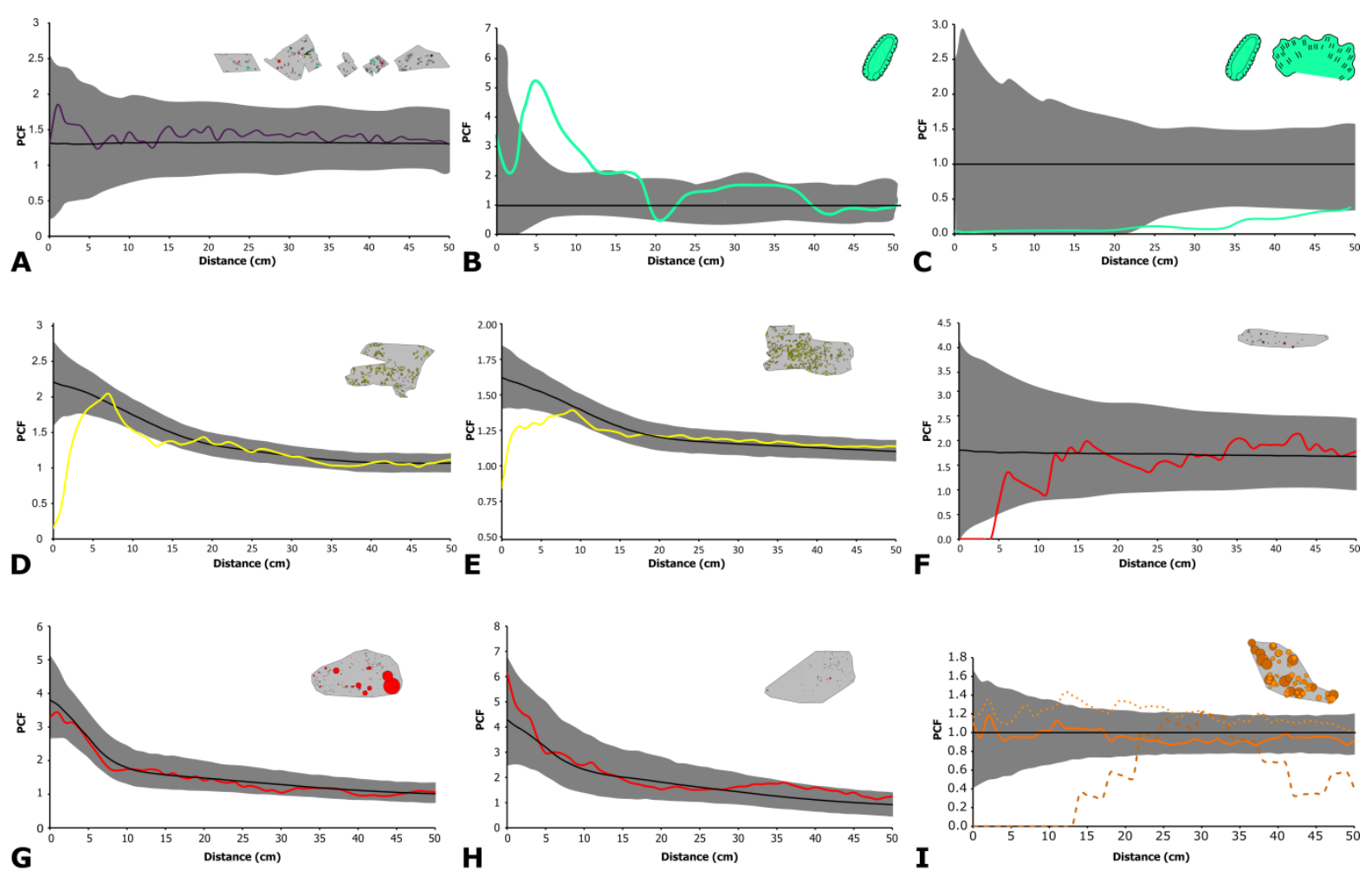

Fig. 3. Pair correlation functions describing the spatial distributions of the seven studied

palaeocommunities. The coloured lines are the observed data and black lines represent best-

fit models (either CSR or heterogeneous Poisson). The grey area is the simulation envelope for 999 Monte Carlo simulations. The x-axis is the inter-point distance between organisms in centimetres. On the $y$-axis, $\mathrm{PCF}=1$ indicates complete spatial randomness $(\mathrm{CSR}),<1$ indicates segregation, and > 1 indicates aggregation. A) The KS surfaces showing sessile specimens with the black-line showing the best-fit heterogeneous Poisson model. B) KS univariate Kimberella. C) KS bivariate Kimberella - Kimberichnus with the CSR model shown. D) FUN4, and E) 
398 Poisson models. I) Dickinsonia from DS with the solid line showing the whole population, 399 dotted line the juveniles and dashed line the adults with the CSR model shown.

400

\begin{tabular}{|c|c|c|c|c|c|c|c|}
\hline \multirow{2}{*}{ SURFACE } & \multirow{2}{*}{ TAXON } & \multirow{2}{*}{$\mathbf{N}$} & \multicolumn{5}{|c|}{$P_{D} V A L U E S$ PCF } \\
\hline & & & CSR & HP & TC & DTC & ITC \\
\hline$W S$ & Aspidella & 40 & 0.019 & 0.796 & 0.504 & 0.2759 & 0.425 \\
\hline KH1 & Aspidella & 204 & 0.001 & 0.001 & 0.648 & 0.883 & 0.313 \\
\hline $\mathrm{KH} 2$ & Aspidella & 81 & 0.001 & 0.001 & 0.576 & 0.932 & 0.001 \\
\hline FUN4 & Funisia & 290 & 0.001 & 0.9570 & 0.6340 & NA & 0.245 \\
\hline FUN5 & Funisia & 482 & 0.001 & 0.9080 & 0.1320 & NA & 0.218 \\
\hline \multirow[t]{3}{*}{$D S$} & Dickinsonia & 62 & 0.857 & 0.022 & 0.025 & NA & 0.019 \\
\hline & Dickinsonia Small & 48 & 0.128 & 0.978 & 0.143 & NA & 0.158 \\
\hline & Dickinsonia Large & 14 & 0.388 & 0.446 & 0.409 & NA & 0.434 \\
\hline \multirow[t]{6}{*}{$K S$} & All & 107 & 0.858 & 0.381 & 0.328 & NA & 0.380 \\
\hline & All sessile & 44 & 0.033 & 0.956 & 0.770 & NA & 0.761 \\
\hline & Kimberella & 18 & 0.001 & 0.837 & 0.491 & NA & 0.103 \\
\hline & Orbisiana & 16 & 0.325 & 0.332 & 0.326 & NA & 0.288 \\
\hline & Kimberichnus & 6 & 0.566 & NA & NA & NA & NA \\
\hline & Bivariate Kimberella-Kimberichnus & 24 & 0.028 & NA & NA & NA & NA \\
\hline
\end{tabular}

401

402 Table 2. Goodness-of-fit tests for spatial analyses. For the inhomogeneous point processes

403 (HP and ITC), the moving window radius is $0.5 \mathrm{~m}$, using the same taxon density as the taxon

404 being modelled. $p_{d}=1$ corresponds to a perfect fit of the model to the data, while $p_{d}=0$

405 corresponds to no fit. Where observed data did not fall outside CSR Monte-Carlo simulation

406 envelopes, no further analyses were performed, which is indicated by NA. CSR: Complete

407 spatial randomness indicates, HP: Heterogeneous Poisson model, TC: Thomas cluster model,

408 DTC: double Thomas Cluster, and ITC: inhomogeneous Thomas cluster model. $\mathrm{N}$ is the 409 number of specimens mapped. Note that for the mobile taxa Dickinsonia and Kimberella, and

410 presumed trace fossils formed by mobile taxa (Kimberichnus), the observed spatial pattern will

411 also be defined by their behaviour, and so the inference of process from pattern is not as 412 straightforward (see discussion in the main text). The $\mathrm{p}_{\mathrm{d}}$-value of the best-fit model is given 413 in bold. 
415 The KS community is notably different in species composition from deep-water communities

416 because it contains mobile organisms such as Kimberella and Yorgia (96-99) as well as

417 putative trace fossils such as Radulichus (thought to be produced by the grazing activity of

418 Kimberella specimens) (100). We found that the KS community exhibits CSR, which suggests

419 that any taxon-specific univariate distributions are likely to be biological/ecological in origin,

420 rather than resulting from a taphonomic bias $\left(p_{d}{ }^{K S}{ }_{A l l}=0.858\right.$, Table 2, (23)). In contrast, when

421 all the sessile taxa were grouped together they exhibited a significant aggregation (Table 2),

422 which was best-modelled by a heterogeneous Poisson process $\left(p_{d}{ }^{K S}{ }_{\text {Sessile }}=0.956\right.$, Table 2).

423 Kimberella exhibits a significant aggregation under spatial scales of $20 \mathrm{~cm}\left(p_{d}{ }^{K S}{ }_{\text {Kimberella }}\right.$

$424=0.001$ for CSR model, Fig. 3A), with Thomas cluster and heterogeneous Poisson models

425 fitting the data well, suggesting that behaviour factors may also influence Kimberella spatial patterns. The Kimberichnus PCF spatial distribution has a CSR distribution (Fig. 3B, $p_{d}{ }^{K S}{ }_{\text {Rad }}$ $=0.566$, Table 2). Furthermore, the bivariate analyses between Kimberella and Kimberichnus show a significant segregation $\left(p_{d}{ }^{K S}{ }_{\text {KimRad }}=0.028\right.$, Fig 3C), which could reflect the Kimberella organisms avoiding patches of the surface that had already been grazed.

The Dickinsonia population from DS exhibited a CSR PCF distribution (Fig 3I, $p_{d}=0.857$ ). aggregating with a best-fit heterogeneous Poisson model $\left(\right.$ Fig $\left.3 \mathrm{I}, p_{d}^{\text {small }}=0.978\right)$ and the large specimens exhibiting segregation (Fig. 3I).

438 For mobile organisms, inferring the underlying process behind the observed spatial distributions is imprecise, since their spatial patterns also incorporate contributions from their 
440 behavior. Modern animals move primarily to find resources, mates, microhabitats and/or 441 escape predators or detrimental environmental conditions. There is no evidence for predators 442 until the terminal Ediacaran (101), and although we cannot definitely rule out reproductive 443 aggregations, they are also considered unlikely because the largest size-class in the studied

444 Dickinsonia population exhibits univariate segregation, so at time-of-burial, the organisms 445 were not aggregating as might be expected in a mating event. Furthermore, the majority of 446 extant marine benthic organisms use broadcast spawning to reproduce sexually (102), so do 447 not require the two mating organisms to be within the spatial scale $(<40 \mathrm{~cm})$ found on the DS 448 surface. We cannot determine whether the large Dickinsonia are reacting to the mortality event 449 which killed and preserved them, however, this would not explain the complex interplay 450 between aggregation and segregated behaviors. Therefore, for this Dickinsonia population, the search for resources and/or microhabitats is considered most plausible explanation, particularly since this hypothesis is further supported by their spatial patterns. Aggregated - segregated PCF patterns such as those seen in our Dickinsonia population are common in extant sessile organisms where juveniles are initially aggregated on preferred habitats but then begin to compete with each other as they require greater resources, leading to thinning or segregation amongst adult populations (55). While it is not possible to confirm the underlying mechanism for the distribution of the studied Dickinsonia population, we consider it most likely to be motivated by associations with preferential habitat for food and/or resources. Further analyses of other Dickinsonia surfaces would enable more robust conclusions to be reached.

\section{Time averaging}

462 The preservation of time-averaged communities has the potential to bias our analyses (see

463 (21,25). In Avalonian communities, taphomorphs interpreted to record the decaying remains of organisms are identified by their poor preservational fidelity, irregular morphologies, and 
465 often high topographic relief (103). This interpretation is consistent with data suggesting that

466 the spatial interactions of some taphomorph populations mirror those of other taxa they are

467 considered to be derived from (21). Taphomorphs are considered unlikely to have imparted a

468 significant signal on these studied surfaces, since we did not observe ivesheadiomorph-type

469 forms, and there is a consistent level of preservational detail amongst fossil communities

470

471 Funisia communities tend to have very similar diameters for the holdfasts, which suggests single colonization events (104). Different reproductive events can be distinguished by population analyses of size-distributions (105), with each reproductive event identified through statistically significant cohorts within the size-distribution (90). Surfaces FUN4 and FUN5

475 both exhibit populations with two cohorts (SI Figure 1), most likely indicating two reproductive/colonization events. The best-fit models for each of these surfaces are heterogeneous Poisson models (Fig. 3, Table 2), with very high goodness-of-fit values $\left(p_{d}>\right.$ 0.90) reflecting a single model for each surface. Therefore, cohorts of Funisia specimens on each of the studied surfaces were affected by the same underlying environmental heterogeneity, so most likely were contemporaneous.

\section{Discussion}

483 The univariate and bivariate analyses of five out of seven of the studied palaeocommunities 484 provide compelling evidence that their local environment had a significant influence on their communities (Fig. 3, Table 2). In modern settings, habitat associations form when a patchy resource provides heterogeneously distributed preferential conditions for the establishment and growth of sessile taxa, and/or feeding 'hotspots' for the mobile taxa $(47,54,83)$. The presence of inferred habitat interactions within our palaeocommunities showed a significant correlation with the environmental setting (Kruskal-Wallis Test, $p=0.049$ ), with all five 
490 palaeocommunities with strong habitat interactions derived from shallow-water settings. The

491 two communities that were seemingly not strongly influenced by their local habitat are from

492 deep-water facies (Table 2). These results are consistent with previous work, which found

493 that for seven independent deep-marine (slope and basin) Ediacaran palaeocommunities from

494 Newfoundland and Charnwood Forest, only one was dominated by associations of taxa with

495 local habitat heterogeneities (21-23) (Kruskal-Wallis Test of all data, $p=0.021$; Fig. 4).

496

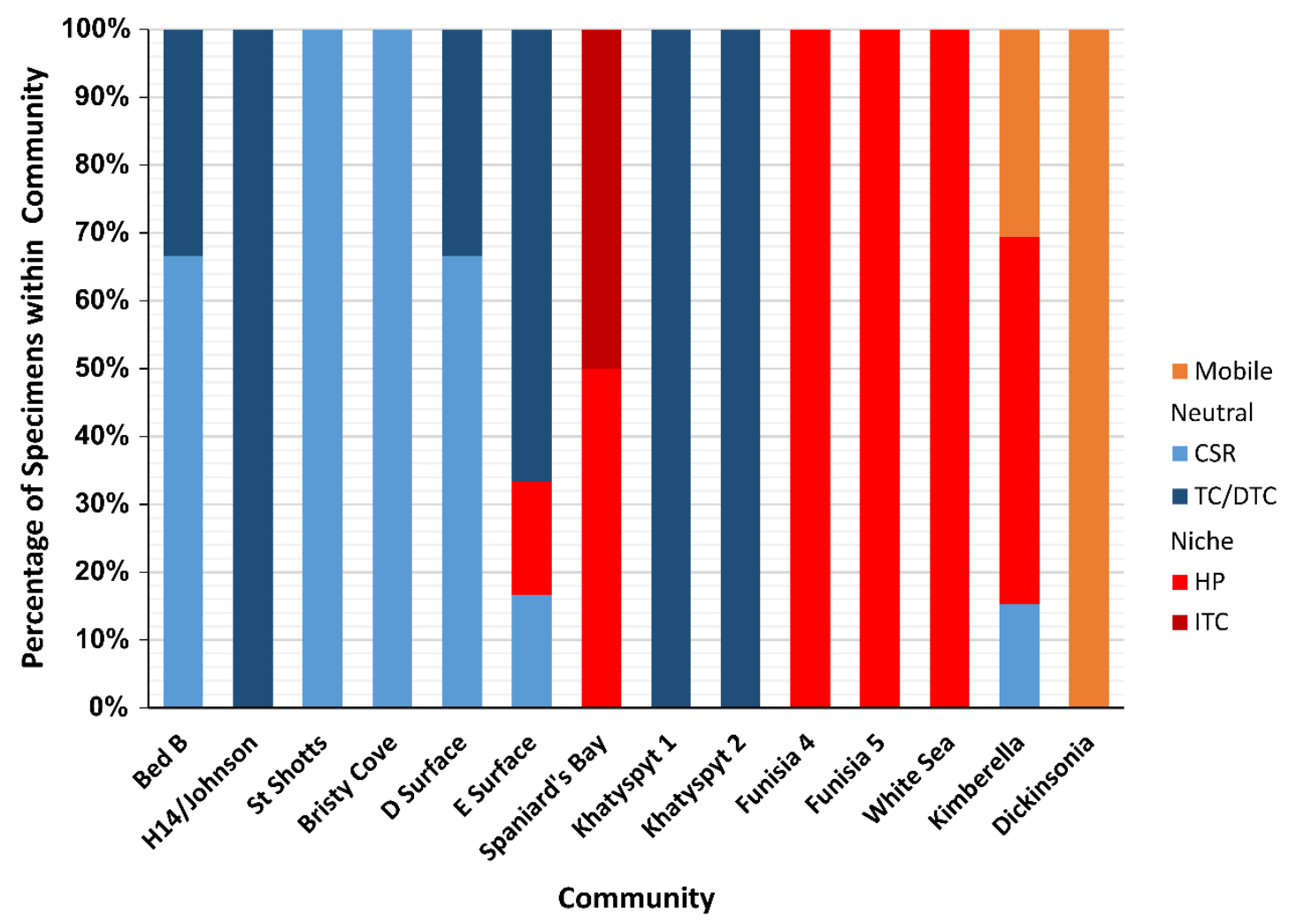

497

498 Fig. 4 Proportion of best-fit univariate models by surface, adapted from (23). The

499 percentage of specimens within the community with univariate spatial distributions that are

500 best described by CSR, HP, TC (or DTC) and ITC models. CSR and TC are considered random

501 or dispersal (neutral) models and are shown in blue. HP and ITC are local environmentally

502 driven (niche) models, shown in red. Mobile taxa are shown in orange, and inferred to be

503 environmentally-driven. Data and plot for surfaces Bed B to Spaniard's Bay from ref. (23). 
505 Untangling environmental from evolutionary trends in the Ediacaran has been hampered by a

506 limited overlap between temporal periods and environmental settings $(1,17)$. The

507 palaeocommunities in this study derive from successions within a variety of lithologies (tuff,

508 coarse sandstone, mixed siltstone, limestone) as well as palaeogeographic positions

$509(17,62,63,69,104,106,107)$. We find no significant direct correlations between these factors and

510 the relative importance of habitat heterogeneities on the studied surfaces $(p>>0.1$; Fig. 3 ,

511 Table 2). The palaeocommunities that are not influenced by local habitat heterogeneities (KH1

512 and KH2) are hosted within carbonate successions (107), making them distinct from the

513 siliciclastically-hosted palaeocommunities on the KS, WS, FUN4, FUN5 and DS surfaces, or

514 in previous (21-23) work. However, the Khatyspyt surfaces behave ecologically in the same

515 way to Avalonian palaeocommunities derived from similar depths, but different lithological

516 successions (21-23), suggesting that lithology alone is not causing the KH1 and KH2 surfaces

517 differing results. Therefore, two possible factors remain that may explain the differences in

518 community dynamics found here. The differences could reflect evolutionary trends, and it is

519 true that the oldest studied palaeocommunities show limited habitat influence (21-23), when

520 compared to the younger palaeocommunities documented in this study (Fig. 4). Unfortunately,

521 the lack of fine-scale dating across these communities and older Avalonian ones precludes

522 detailed fine-scale regression to assess whether either the Khatyspyt palaeocommunities are an

523 outlier to this apparent trend, or this trend merely reflects the biases of the available data.

524 Alternatively, the differences could be due to the environmental setting. We have shown that

525 Ediacaran environmental setting has a significant influence on community dynamics $(p=$

526 0.021), with shallow water palaeocommunities significantly influenced by habitat

527 heterogeneities, in contrast to the deep water palaeocommunities (Fig 3, Table 2; (21-23)). 
529 While SPPA have only been applied to a small proportion of the known in-situ Ediacaran 530 palaeocommunities (17 studied surfaces $(21-23,23,60,108))$, there is a notable correspondence

531 between the importance of habitat heterogeneities to community ecology and assemblage

532 diversity. In this study, the palaeocommunities exhibiting significant influence from local

533 habitat heterogeneities are those that belong to the diverse White Sea assemblage, which is in

534 contrast to the previous work on Avalonian palaeocommunities (21-23), which are not significantly influenced by such heterogeneities. The relationship between environmental spatial heterogeneities and species richness is well established, with habitat variations enabling species co-existence through the creation of different niches (109). This relationship extends to modern deep-sea benthic communities, where these heterogeneities have been shown to

539 provide a mechanism for diversification on large scales, such as between canyons, trenches, seamounts $(110,111)$, on the centimetre to metre scale (112), and through microhabitats (45).

542 Tentatively, we propose that the ecological differentiation observed between Ediacaran

543 shallow and deep-water communities may evidence the late Ediacaran development of a chain

544 of evolutionary diversification. This chain started in shallow water communities, with the creation of habitat patchiness by mobile Ediacaran organisms, which then led to a feedback of increasing diversification that ultimately expanded into the deep-sea. This hypothesized

547 feedback could have promoted diversification throughout the Ediacaran by increasing 548 heterogeneity as follows:

550 First, metazoan mat grazing creates spatial heterogeneity in microbial substrates through the 551 formation of depleted and non-depleted patches (113). Our data suggest that once created, 552 organisms such as Kimberella may have avoided pre-grazed patches, with this selective grazing 553 accelerating further creation of mat heterogeneity (Fig 3C). Secondly, the grazing-induced 
creation of different-sized detrital particles in the form of differential-sized fecal pellets and fragments of non-consumed food within the water-column (114), would have created new food sources and therefore potential new niches. Thirdly, this shallow-water differentiated particulate organic carbon (POC) and matter (POM) could have eventually filtered through to deep-sea communities, promoting deep-sea heterogeneity. In the modern ocean, the main source of deep-sea habitat heterogeneity is small-scale variation due to differentiated particle influx (114), with the majority of the particulate organic carbon (POC) coming from phytodetritus, which is transported from shallow waters to deep waters by ocean currents, tides and upwelling $(114,116)$. In the modern ocean, the diurnal vertical migration of mesozooplankton and macrofauna contributes up to $50 \%$ of POC to the deep-sea via fecal pellets (116-118). A planktonic/larval stage for Ediacaran organisms has been predicted on the basis of their likely waterborne dispersal mechanisms $(25,105)$, but there is presently no direct evidence of non-larval, planktotrophic zooplankton until the onset of the Cambrian (119). In the absence of planktotrophic zooplankton and macrofauna, the Ediacaran POC flux may have been either larger, due to lack of consumption of phytoplankton in the shallow water, or smaller, due to a lack of mixing by diurnal vertical migration of the plankton (6), and this cannot yet be determined. However, the other $\sim 50 \%$ of POC flux in the modern oceans is transported from shallow to deep-water via oceanic currents and upwelling $(114,116)$, which should still have operated in the Ediacaran. However, prior to grazers and detritivores, this POC/POM flux would have been relatively homogenous phytodetritus. The evolution of grazers would have led to a shift towards size differentiated POC/POM, potentially increasing the heterogeneity of the deep-sea landscape (114), and providing a mechanism for deep-marine diversification. 
578 Budd and Jensen (12) introduced the Savannah hypothesis to explain early animal 579 diversification, whereby Ediacaran diversification was driven by small-scale variations in local

580 habitat. They argued that it was the drive to find these heterogeneous distributed resources that

581 led to novel evolutionary innovations such as mobility. Our results demonstrate that at least

582 some of these early animal communities that contain mobile organisms were influenced by

583 such habitat variations, and we describe a mechanism that links early animal diversification

584 and benthic habitat patchiness prior to the evolution of predators and wide-spread pelagic

585 organisms. We show that taxa such as Kimberella had a segregated distribution with trace

586 fossils considered to be their grazing traces (98), suggesting that they may have been capable

587 of avoiding non-preferred areas, possibly already consumed patches, revealing adaptation of

588 behavior when interacting with these patches. This adaptation theoretically has the capacity to

589 drive further diversification, initially dependent on the environmental-setting, starting in the

590 shallow water, and then, over time, moving into deeper water, but currently available global

591 fossil assemblages limit the testing of this prediction. If this hypothesis is correct, we would

592 expect deep-water assemblages to diversify during the terminal Ediacaran and into the

593 Cambrian. Our results therefore provide tentative support for the Savannah hypothesis,

594 suggesting that this late Ediacaran taxonomic diversification was a benthic event, which

595 facilitated a chain of diversification by promoting marine habitat heterogeneities. 


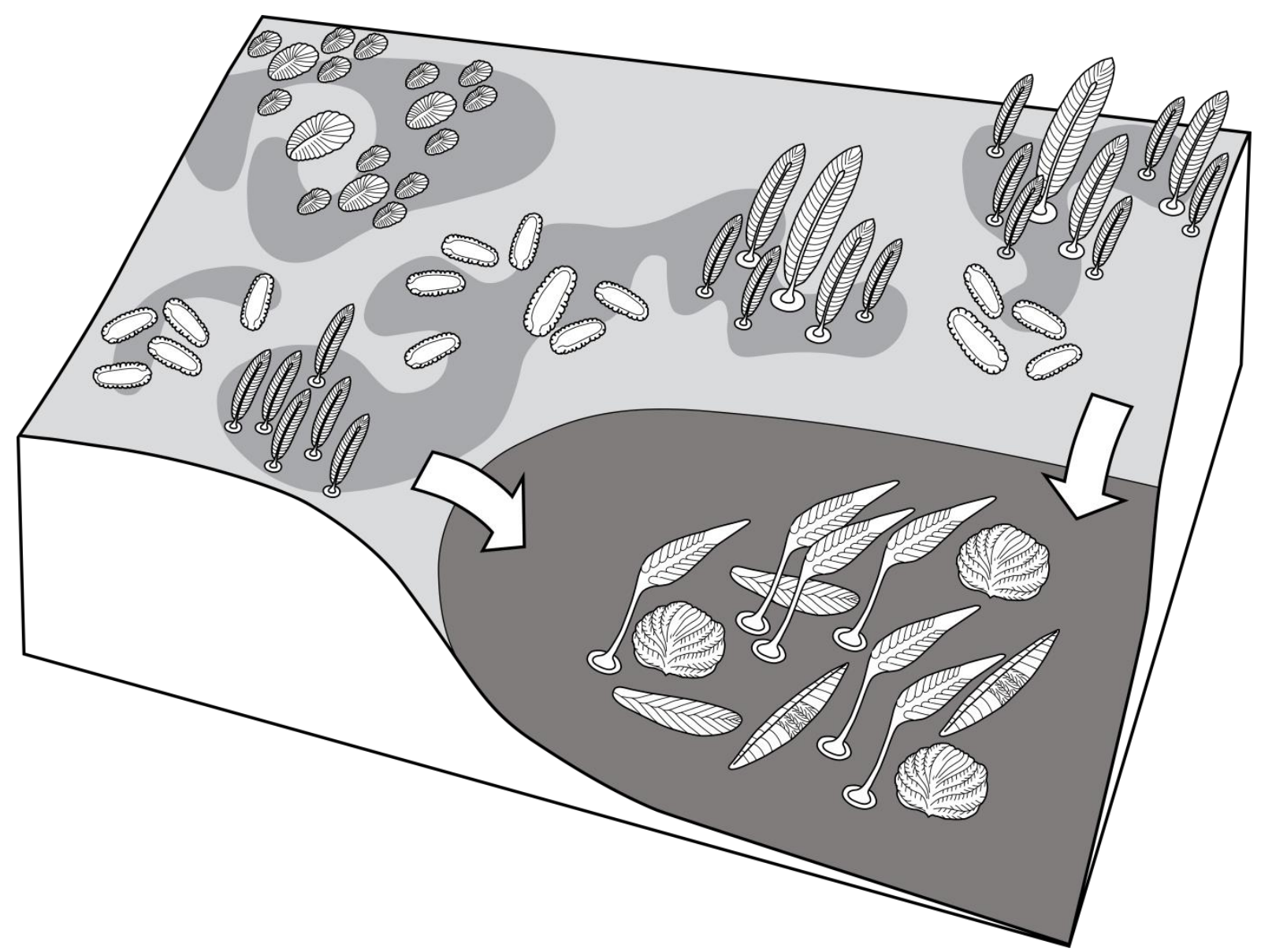

598 Fig. 5. Schematic diagram showing variation of heterogeneities within different

599 environmental settings. Shallow water communities are significantly influenced by habitat

600 heterogeneities. Grazing within these shallow waters further increases substrate heterogeneity,

601 potentially increasing diversification. Furthermore, this grazing increases deep-water

602 heterogeneity through the creation of different sized particulate organic matter due to the influx 603 of particulate matter from the shallows.

\section{Conclusions}

606 We present evidence to suggest that the influence of local habitat on Ediacaran organisms is 607 significantly correlated with broad-scale environmental setting. The relationship of Ediacaran 608 communities to habitat-dependent interactions is correlated with Ediacaran assemblage diversity, with communities from the more diverse White Sea assemblage showing significant 
610 habitat associations and interactions in contrast to relatively habitat insensitive deep-sea

611 Avalonian assemblages. We suggest that the presence of shallow-water grazers could have

612 created further habitat heterogeneity in shallow-water and ultimately deep-water, via the

613 heterogenization of the shallow-water substrate and via the introduction of variable size

614 particulate matter to the deep-sea. These results demonstrate the utility of these approaches for

615 investigating the early diversification of metazoans. We have shown the importance of local

616 environmental patchiness to the diversification of early animals, and our results are consistent

617 with the hypothesis that the early diversification of metazoans was a benthic event, driven by

618 responses to habitat patchiness.

619

620 Acknowledgements

621 We thank K. Nagovitsin and O. Zharasbayev (IPGG SB RAS) for help with mapping surfaces

$622 \mathrm{KH} 1$ and KH2, and J. Gehling and M. Binnie of the South Australia Museum for assisting with 623 access to Australian material.

\section{Funding}

626 This work has been supported by the Natural Environment Research Council [grant numbers

627 NE/P002412/1 and Independent Research Fellowship NE/S014756/1 EGM, and Independent

628 Research Fellowship NE/L011409/2 to AGL], a Gibbs Travelling Fellowship (2016-2017)

629 from Newnham College, Cambridge, and a Henslow Research Fellowship from Cambridge

630 Philosophical Society to EGM (2016-2019). Field research in the White Sea Region, Arctic

631 Siberia and Central Urals has been supported by the Russian Science Foundation [grant number

632 17-17-01241 to DG]. SX acknowledges funding from the NASA Exobiology and Evolutionary

633 Biology Program [80NSSC18K1086]. Large image processing and interpretation of 
634 photomontages of the Dickinsonia Surface was supported by the Russian Foundation for Basic 635 Research [grant number 19-05-00828 to AVK].

636

\section{References}

1. Wood R, Liu AG, Bowyer F, Wilby PR, Dunn FS, Kenchington CG, et al. Integrated records of environmental change and evolution challenge the Cambrian Explosion. Nat Ecol Evol. 2019;3(4):528-38.

2. Xiao S, Laflamme M. On the eve of animal radiation: phylogeny, ecology and evolution of the Ediacara biota. Trends in Ecology and Evolution. 2009;24(1):31-40.

3. Erwin DH, Laflamme M, Tweedt SM, Sperling EA, Pisani D, Peterson KJ. The Cambrian Animals. Science. 2011 Nov 25;334(6059):1091-7.

4. Lenton TM, Boyle RA, Poulton SW, Shields-Zhou GA, Butterfield NJ. Co-evolution of eukaryotes and ocean oxygenation in the Neoproterozoic era. Nature Geoscience. 2014;7(4):257-65.

5. Butterfield NJ. Macroevolutionary turnover through the Ediacaran transition: ecological and biogeochemical implications. Geological Society, London, Special Publications. 2009;326(1):55-66.

6. Butterfield NJ. Oxygen, animals and aquatic bioturbation: An updated account. Geobiology. 2018;16(1):3-16.

7. Sperling EA, Frieder CA, Raman AV, Girguis PR, Levin LA, Knoll AH. Oxygen, ecology, and the Cambrian radiation of animals. PNAS. 2013 Aug 13;110(33):13446-51.

8. Lenton TM, Daines SJ. The effects of marine eukaryote evolution on phosphorus, carbon and oxygen cycling across the Proterozoic-Phanerozoic transition. Emerging Topics in Life Sciences. 2018;2(2):267-78. 
659 9. Wood R, Erwin DH. Innovation not recovery: dynamic redox promotes metazoan radiations. Biological Reviews. 2018;93(2):863-73.

661

10. Butterfield NJ. Animals and the invention of the Phanerozoic Earth system. Trends in Ecology \& Evolution. 2011 Feb 1;26(2):81-7.

11. Mángano MG, Buatois LA. Decoupling of body-plan diversification and ecological structuring during the Ediacaran-Cambrian transition: evolutionary and geobiological feedbacks. Proceedings of the Royal Society B: Biological Sciences. 2014 Apr 7;281(1780):20140038.

12. Budd GE, Jensen S. The origin of the animals and a 'Savannah' hypothesis for early bilaterian evolution. Biological Reviews. 2017;92(1):446-73.

13. Muscente AD, Boag TH, Bykova N, Schiffbauer JD. Environmental disturbance, resource availability, and biologic turnover at the dawn of animal life. Earth-Science Reviews. 2018 Feb 1;177:248-64.

14. McPeek MA. The Ecological Dynamics of Natural Selection: Traits and the Coevolution of Community Structure. The American Naturalist. 2017 May 1;189(5):E91-117.

15. Waggoner B. The Ediacaran Biotas in Space and Time. Integr Comp Biol. 2003 Feb $1 ; 43(1): 104-13$.

16. Grazhdankin D. Patterns of distribution in the Ediacaran biotas: facies versus biogeography and evolution. Paleobiology. 2004 Mar 1;30(2):203-21.

17. Boag TH, Darroch SAF, Laflamme M. Ediacaran distributions in space and time: testing assemblage concepts of earliest macroscopic body fossils. Paleobiology. 2016;42(4):57494. analysis of the late Neoproterozoic Mistaken Point and Trepassey formations, southeastern Newfoundland. Canadian Journal of Earth Sciences. 2003 Oct 1;40(10):1375-91. 
684 19. Gehling JG, Droser ML. How well do fossil assemblages of the Ediacara Biota tell time? Geology. 2013 Apr 1;41(4):447-50.

686

20. Clapham ME, Narbonne GM, Gehling JG. Paleoecology of the oldest known animal communities: Ediacaran assemblages at Mistaken Point, Newfoundland. Paleobiology. 2003;29(4):527-44.

690

21. Mitchell EG, Butterfield NJ. Spatial analyses of Ediacaran communities at Mistaken Point.

691

692

693

694

695

696

697

698

699

700

701

702

703

704

705

706

707

$$
\text { Paleobiology. } 2018 \text { Feb 1;44(1):40-57. }
$$

22. Mitchell EG, Kenchington CG. The utility of height for the Ediacaran organisms of Mistaken Point. Nat Ecol Evol. 2018 Aug;2(8):1218-22.

23. Mitchell EG, Harris S, Kenchington CG, Vixseboxse P, Roberts L, Clark C, et al. The importance of neutral over niche processes in structuring Ediacaran early animal communities. Ecology Letters. 2019;22(12):2028-38.

24. Coutts FJ, Gehling JG, García-Bellido DC. How diverse were early animal communities? An example from Ediacara Conservation Park, Flinders Ranges, South Australia. Alcheringa: An Australasian Journal of Palaeontology. 2016 Oct 24;40(4):407-21.

25. Mitchell EG, Kenchington CG, Liu AG, Matthews JJ, Butterfield NJ. Reconstructing the reproductive mode of an Ediacaran macro-organism. Nature. 2015 Aug;524(7565):343-6.

26. Wilby PR, Carney JN, Howe MPA. A rich Ediacaran assemblage from eastern Avalonia: Evidence of early widespread diversity in the deep ocean. Geology. 2011;39(7):655-8.

27. Narbonne GM. THE EDIACARA BIOTA: Neoproterozoic Origin of Animals and Their Ecosystems. Annual Review of Earth and Planetary Sciences. 2005;33(1):421-42.

28. Pu JP, Bowring SA, Ramezani J, Myrow P, Raub TD, Landing E, et al. Dodging snowballs: Geochronology of the Gaskiers glaciation and the first appearance of the Ediacaran biota. Geology. 2016;44(11):955-8. 
29. Noble SR, Condon DJ, Carney JN, Wilby PR, Pharaoh TC, Ford TD. U-Pb geochronology and global context of the Charnian Supergroup, UK: Constraints on the age of key Ediacaran fossil assemblages. GSA Bulletin. 2015 Jan 1;127(1-2):250-65.

30. Bush AM, Bambach RK, Erwin DH. Ecospace Utilization During the Ediacaran Radiation and the Cambrian Eco-explosion. Quantifying the Evolution of Early Life. 2011;111-33.

31. Shen B, Dong L, Xiao S, Kowalewski M. The Avalon Explosion: Evolution of Ediacara Morphospace. Science. 2008 Jan 4;319(5859):81-4.

32. Liu AG, Mcllroy D, Brasier MD. First evidence for locomotion in the Ediacara biota from the 565 Ma Mistaken Point Formation, Newfoundland. Geology. 2010 Feb 1;38(2):123-6.

33. Gage JD, Tyler PA. Re-appraisal of age composition, growth and survivorship of the deepsea brittle star <Emphasis Type="Italic">Ophiura ljungmani</Emphasis $>$ from size structure in a sample time series from the Rockall Trough. Mar Biol. 1981 Sep $1 ; 64(2): 163-72$.

34. Tecchio S, Ramírez-Llodra E, Sardà F, Company JB. Biodiversity of deep-sea demersal megafauna in western and central Mediterranean basins. Scientia Marina. 2011;75(2):34150.

35. Seilacher A, Grazhdankin D, Legouta A. Ediacaran biota: The dawn of animal life in the shadow of giant protists. Paleontological Research. 2003;7(1):43-54.

36. Droser ML, Gehling JG. The advent of animals: The view from the Ediacaran. PNAS. 2015 Apr 21;112(16):4865-70.

37. Duda J-P, Blumenberg M, Thiel V, Simon K, Zhu M, Reitner J. Geobiology of a palaeoecosystem with Ediacara-type fossils: The Shibantan Member (Dengying Formation, South China). Precambrian Research. 2014 Dec 1;255:48-62.

38. Chen Z, Chen X, Zhou C, Yuan X, Xiao S. Late Ediacaran trackways produced by bilaterian animals with paired appendages. Science Advances. 2018 Jun 1;4(6):eaao6691. 
733

734

735

736

737

738

739

740

741

742

743

744

745

746

747

748

749

750

751

752

753

754

755

756

39. Sperling EA, Vinther J. A placozoan affinity for Dickinsonia and the evolution of late Proterozoic metazoan feeding modes. Evolution \& Development. 2010;12(2):201-9.

40. Gehling JG, Droser ML. Ediacaran scavenging as a prelude to predation. Emerging Topics in Life Sciences. 2018;2(2):213-22.

41. Seilacher A, Buatois LA, Gabriela Mángano M. Trace fossils in the Ediacaran-Cambrian transition: Behavioral diversification, ecological turnover and environmental shift. Palaeogeography, Palaeoclimatology, Palaeoecology. 2005 Nov 10;227(4):323-56.

42. Droser ML, Gehling JG, Tarhan LG, Evans SD, Hall CMS, Hughes IV, et al. Piecing together the puzzle of the Ediacara Biota: Excavation and reconstruction at the Ediacara National Heritage site Nilpena (South Australia). Palaeogeography, Palaeoclimatology, Palaeoecology. 2019 Jan 1;513:132-45.

43. Reid LM, García-Bellido DC, Gehling JG. An Ediacaran opportunist? Characteristics of a juvenile Dickinsonia costata population from Crisp Gorge, South AustraliaReid et al. -Population analysis of Dickinsonia costata from South AustraliaJournal of Paleontology. Journal of Paleontology. 2018;92(3):313-22.

44. Finnegan S, Gehling JG, Droser ML. Unusually variable paleocommunity composition in the oldest metazoan fossil assemblages. Paleobiology. 2019 May;45(2):235-45.

45. Kukert H, Smith CR. Disturbance, colonization and succession in a deep-sea sediment community: artificial-mound experiments. Deep Sea Research Part A Oceanographic Research Papers. 1992 Jul 1;39(7):1349-71.

46. Liu AG, Kenchington CG, Mitchell EG. Remarkable insights into the paleoecology of the Avalonian Ediacaran macrobiota. Gondwana Research. 2015 Jun 1;27(4):1355-80.

47. Illian DJ, Penttinen PA, Stoyan DH, Stoyan DD. Statistical Analysis and Modelling of Spatial Point Patterns. John Wiley \& Sons; 2008. 557 p. 
757

758

759

760

761

762

763

764

765

766

767

768

769

770

771

772

773

774

775

776

777

778

779

780

781

48. Wiegand T, Gunatilleke S, Gunatilleke N, Okuda T. Analyzing the Spatial Structure of a Sri Lankan Tree Species with Multiple Scales of Clustering. Ecology. 2007;88(12):3088102.

49. Seidler TG, Plotkin JB. Seed Dispersal and Spatial Pattern in Tropical Trees. PLOS Biology. 2006 Oct 17;4(11):e344.

50. Getzin S, Dean C, He F, Trofymow JA, Wiegand K, Wiegand T. Spatial patterns and competition of tree species in a Douglas-fir chronosequence on Vancouver Island. Ecography. 2006;29(5):671-82.

51. Lingua E, Cherubini P, Motta R, Nola P. Spatial structure along an altitudinal gradient in the Italian central Alps suggests competition and facilitation among coniferous species. Journal of Vegetation Science. 2008;19(3):425-36.

52. Getzin S, Dean C, He F, Trofymow JA, Wiegand K, Wiegand T. Heterogeneity influences spatial patterns and demographics in forest stands. Journal of Ecology. 2008;96(4):80720.

53. Harms KE, Wright SJ, Calderón O, Hernández A, Herre EA. Pervasive density-dependent recruitment enhances seedling diversity in a tropical forest. Nature. 2000 Mar;404(6777):493-5.

54. Lin Y-C, Chang L-W, Yang K-C, Wang H-H, Sun I-F. Point patterns of tree distribution determined by habitat heterogeneity and dispersal limitation. Oecologia. 2011 Jan $1 ; 165(1): 175-84$.

55. Kenkel NC. Pattern of Self-Thinning in Jack Pine: Testing the Random Mortality Hypothesis. Ecology. 1988;69(4):1017-24.

56. Diggle $\mathrm{P}$, Zheng $\mathrm{P}$, Durr P. Nonparametric estimation of spatial segregation in a multivariate point process: bovine tuberculosis in Cornwall, UK. Journal of the Royal Statistical Society: Series C (Applied Statistics). 2005;54(3):645-58. 
57. Law R, Illian J, Burslem DFRP, Gratzer G, Gunatilleke CVS, Gunatilleke I a. UN. Ecological information from spatial patterns of plants: insights from point process theory. Journal of Ecology. 2009;97(4):616-28.

58. Comita L, Condit R, Hubbell SP. Developmental changes in habitat associations of tropical trees. Journal of Ecology. 2007;95:482-92.

59. Wiegand T, Moloney KA, Moloney KA. Handbook of Spatial Point-Pattern Analysis in Ecology. 1st ed. Chapman and Hall/CRC; 2013.

60. Mitchell EG, Kenchington CG, Harris S, Wilby PR. Revealing rangeomorph species characters using spatial analyses. Canadian Journal of Earth Sciences. 2018 Nov $1 ; 55(11): 1262-70$.

61. Grazhdankin D. The Ediacaran genus Inaria: a taphonomicl morphodynamic analysis. Neues Jahrbuch für Geologie und Paläontologie - Abhandlungen. 2000 Apr 18;1-34.

62. Grazhdankin DV. Structure and Depositional Environment of the Vendian Complex in the Southeastern White Sea Area. Stratigraphy and Geological Correlation. 2003;11(4):31331.

63. Grazhdankin DV, Maslov AV, Krupenin MT. Structure and depositional history of the Vendian Sylvitsa Group in the western flank of the Central Urals. Stratigr Geol Correl. 2009 Oct 9;17(5):476.

64. Schmitz M, editor. In: The Geologic Time Scale 2012. Elsevier; 2012. p. 1045-1082.

65. Martin MW, Grazhdankin DV, Bowring SA, Evans D a. D, Fedonkin MA, Kirschvink JL. Age of Neoproterozoic Bilatarian Body and Trace Fossils, White Sea, Russia: Implications for Metazoan Evolution. Science. 2000;288(5467):841-5.

66. Droser ML, Gehling JG, Dzaugis ME, Kennedy MJ, Rice D, Allen MF. A New Ediacaran Fossil with a Novel Sediment Displacive Life HabitA New Ediacaran fossil with a Novel Life Habit. Journal of Paleontology. 2014 Jan 1;88(1):145-51. 
807

808

809

810

811

812

813

814

815

816

817

818

819

820

821

822

823

824

825

826

827

828

829

830

67. Tarhan LG, Droser ML, Gehling JG, Dzaugis MP. Taphonomy and morphology of the Ediacara form genus Aspidella. Precambrian Research. 2015 Feb 1;257:124-36.

68. Reid LM, Payne JL, García-Bellido DC, Jago JB. The Ediacara Member, South Australia: lithofacies and palaeoenvironments of the Ediacara biota. Gondwana Research [Internet]. 2019 Nov 7 [cited 2019 Nov 13]; Available from: http://www.sciencedirect.com/science/article/pii/S1342937X19302862

69. Grazhdankin DV, Maslov Av, Krupenin Mt, Mustill Tmr. The Ediacaran White Sea biota in the Central Urals. Doklady Earth Sciences. 2005;401A(3):382-5.

70. Bobkov NI, Kolesnikov AV, Maslov AV, Grazhdankin D. The occurrence of Dickinsonia in non-marine facies. Estudios geológicos. 75(2):e096.

71. Knoll AH, Grotzinger JP, Kaufman AJ, Kolosov P. Integrated approaches to terminal Proterozoic stratigraphy: an example from the Olenek Uplift, northeastern Siberia. Precambrian Research. 1995 May 1;73(1):251-70.

72. Pelechaty SM, Grotzinger JP, Kashirtsev VA, Zhernovsky VP. Chemostratigraphic and Sequence Stratigraphic Constraints on Vendian-Cambrian Basin Dynamics, Northeast Siberian Craton. The Journal of Geology. 1996 Sep 1;104(5):543-63.

73. Nagovitsin KE, Rogov VI, Marusin VV, Karlova GA, Kolesnikov AV, Bykova NV, et al. Revised Neoproterozoic and Terreneuvian stratigraphy of the Lena-Anabar Basin and north-western slope of the Olenek Uplift, Siberian Platform. Precambrian Research. 2015 Nov 1;270:226-45.

74. Cui H, Grazhdankin DV, Xiao S, Peek S, Rogov VI, Bykova NV, et al. Redox-dependent distribution of early macro-organisms: Evidence from the terminal Ediacaran Khatyspyt Formation in Arctic Siberia. Palaeogeography, Palaeoclimatology, Palaeoecology. 2016 Nov 1;461:122-39. 
831

832

833

834

835

836

837

838

839

840

841

842

843

844

845

846

847

848

849

850

851

852

853

854

75. Vishnevskaya IA, Letnikova EF, Vetrova NI, Kochnev BB, Dril SI. Chemostratigraphy and detrital zircon geochronology of the Neoproterozoic Khorbusuonka Group, Olenek Uplift, Northeastern Siberian platform. Gondwana Research. 2017 Nov 1;51:255-71.

76. Cui H, Xiao S, Cai Y, Peek S, Plummer RE, Kaufman AJ. Sedimentology and chemostratigraphy of the terminal Ediacaran Dengying Formation at the Gaojiashan section, South China. Geological Magazine. 2019 Nov;156(11):1924-48.

77. Evans SD, Gehling JG, Droser ML. Slime travelers: Early evidence of animal mobility and feeding in an organic mat world. Geobiology. 2019;17(5):490-509.

78. Evans SD, Droser ML, Gehling JG. Highly regulated growth and development of the Ediacara macrofossil Dickinsonia costata. Plos One. 2017;

79. Evans SD, Huang W, Gehling JG, Kisailus D, Droser ML. Stretched, mangled, and torn: Responses of the Ediacaran fossil Dickinsonia to variable forces. Geology. 2019 Nov $1 ; 47(11): 1049-53$.

80. Baddeley A, Rubak E, Turner R, Rubak E, Turner R. Spatial Point Patterns : Methodology and Applications with R. Chapman and Hall/CRC; 2015.

81. Berman M. Testing for Spatial Association between a Point Process and Another Stochastic Process. Journal of the Royal Statistical Society: Series C (Applied Statistics). $1986 ; 35(1): 54-62$.

82. Wiegand T, Moloney KA. Rings, circles, and null-models for point pattern analysis in ecology. Oikos. 2004;104(2):209-29.

83. Wiegand T, Wiegand K, Getzin S. Analyzing the Spatial Structure of a Sri Lankan Tree Species with Multiple Scales of Clustering. Ecology. 2007;88(12):3088-102.

84. Wiegand T, Kissling WD, Cipriotti PA, Aguiar MR. Extending point pattern analysis for objects of finite size and irregular shape. Journal of Ecology. 2006;94(4):825-37. 
855

856

857

858

859

860

861

862

863

864

865

866

867

868

869

870

871

872

873

874

875

876

877

878

879

85. Wiegand T, Moloney KA, Naves J, Knauer F. Finding the Missing Link between Landscape Structure and Population Dynamics: A Spatially Explicit Perspective. The American Naturalist. 1999 Dec 1;154(6):605-27.

86. Loosmore NB, Ford ED. Statistical Inference Using the G or K Point Pattern Spatial Statistics. Ecology. 2006;87(8):1925-31.

87. Diggle PJ. Statistical analysis of spatial point patterns. 1983.

88. Levin SA. The Problem of Pattern and Scale in Ecology: The Robert H. MacArthur Award Lecture. Ecology. 1992;73(6):1943-67.

89. Besag J. Spatial Interaction and the Statistical Analysis of Lattice Systems. Journal of the Royal Statistical Society: Series B (Methodological). 1974;36(2):192-225.

90. Fraley C, Raftery AE. MCLUST Version 3 for R: Normal Mixture Modeling and ModelBased Clustering*. 2017;57.

91. Grabarnik P, Myllymäki M, Stoyan D. Correct testing of mark independence for marked point patterns. Ecological Modelling. 2011 Dec 10;222(23):3888-94.

92. Fraley C, Raftery AE. Bayesian Regularization for Normal Mixture Estimation and ModelBased Clustering. Journal of Classification. 2007;24(2):155-81.

93. Pélissier R, Goreaud F. A practical approach to the study of spatial structure in simple cases of heterogeneous vegetation. Journal of Vegetation Science. 2001;12(1):99-108.

94. Chiu SN, Stoyan D, Kendall JM. Stochastic Geometry and Its Applications. 2013.

95. Soznov NG, Bobkov NI, Mitchell EG, Kolesnikov A V, Grazhdankin DV. The ecology of Dickinsonia on tidal flats. IMECT 2019. 2019;

96. Ivantsov AYu. Trace fossils of precambrian metazoans "Vendobionta" and "Mollusks". Stratigr Geol Correl. 2013 May 1;21(3):252-64.

97. Ivantsov AYu. Feeding traces of proarticulata-the Vendian metazoa. Paleontol J. 2011 May 1;45(3):237-48. 
880

881

882

883

884

885

886

887

888

889

890

891

892

893

894

895

896

897

898

899

900

901

902

903

904

98. Ivantsov AYu. New reconstruction of Kimberella, problematic Vendian metazoan. Paleontol J. 2009 Dec 14;43(6):601.

99. Ivantsov A.yu., Malakhovskaya Ya.e. Giant traces of vendian animals. DOKLADY EARTH SCIENCES. 2002;385(6):618-22.

100. Managano MG, Buatois LA. The Cambrian revolutions: Trace-fossil record, timing, links and geobiological impact. Earth-Science Reviews. 2017 Oct 1;173:96-108.

101. Hua H, Pratt BR, Zhang L-Y. Borings in Cloudina Shells: Complex Predator-Prey Dynamics in the Terminal Neoproterozoic. PALAIOS. 2003;18(4-5):454-9.

102. Giangrande A, Geraci S, Belmonte G. Life-cycle and life-history diversity in marine invertebrates and the implications in community dynamics. Oceanographic Literature Review. 1995;8(42):662.

103. Liu AG, Mcilroy D, Antcliffe JB, Brasier MD. Effaced preservation in the Ediacara biota and its implications for the early macrofossil record. Palaeontology. 2011;54(3):60730.

104. Droser ML, Gehling JG. Synchronous Aggregate Growth in an Abundant New Ediacaran Tubular Organism. Science. 2008 Mar 21;319(5870):1660-2.

105. Darroch SAF, Laflamme M, Clapham ME. Population structure of the oldest known macroscopic communities from Mistaken Point, Newfoundland. Paleobiology. 2013;39(4):591-608.

106. Muscente AD, Bykova N, Boag TH, Buatois LA, Mángano MG, Eleish A, et al. Ediacaran biozones identified with network analysis provide evidence for pulsed extinctions of early complex life. Nat Commun [Internet]. 2019 Feb 22 [cited 2019 Oct 14];10. Available from: https://www.ncbi.nlm.nih.gov/pmc/articles/PMC6384941/

107. Grazhdankin DV, Balthasar U, Nagovitsin KE, Kochnev BB. Carbonate-hosted Avalon-type fossils in arctic Siberia. Geology. 2008;36(10):803-6. 
905 108. Reid LM, Holmes JD, Payne JL, García-Bellido DC, Jago JB. Taxa, turnover and 906 taphofacies: a preliminary analysis of facies-assemblage relationships in the Ediacara 907 Member (Flinders Ranges, South Australia). Australian Journal of Earth Sciences. 2018 $908 \quad$ Sep 25;0(0):1-10.

909 109. Ben-Hur E, Kadmon R. Heterogeneity-diversity relationships in sessile organisms: a 910 unified framework. Ecology Letters [Internet]. [cited 2019 Nov 13];n/a(n/a). Available 911 from: https://onlinelibrary.wiley.com/doi/abs/10.1111/ele.13418

912 110. Levin LA, Sibuet M, Gooday AJ, Smith CR, Vanreusel A. The roles of habitat 913 heterogeneity in generating and maintaining biodiversity on continental margins: an 914 introduction. Marine Ecology. 2010;31(1):1-5.

915 111. Vanreusel A, Fonseca G, Danovaro R, Silva MCD, Esteves AM, Ferrero T, et al. The 916 contribution of deep-sea macrohabitat heterogeneity to global nematode diversity. Marine $917 \quad$ Ecology. 2010;31(1):6-20.

918 112. McClain C, Barry JP. Habitat heterogeneity, disturbance, and productivity work in 919 concert to regulate biodiversity in deep submarine canyons. Ecology. 2010;91(4):964-76.

920 113. Sommer S, Pfannkuche O. Metazoan meiofauna of the deep Arabian Sea: standing 921 stocks, size spectra and regional variability in relation to monsoon induced enhanced sedimentation regimes of particulate organic matter. Deep Sea Research Part II: Topical Studies in Oceanography. 2000 Jan 1;47(14):2957-77.

924 114. Leduc D, Rowden AA, Probert PK, Pilditch CA, Nodder SD, Vanreusel A, et al. Further 925 evidence for the effect of particle-size diversity on deep-sea benthic biodiversity. Deep Sea Research Part I: Oceanographic Research Papers. 2012 May 1;63:164-9. 
929 distribution and burial fluxes of particulate organic matter (POM) in the Benguela $930 \quad$ upwelling system. Continental Shelf Research. 2005 Sep 1;25(15):1864-76.

931 116. Manno C, Stowasser G, Enderlein P, Fielding S, Tarling GA. The contribution of 932 zooplankton faecal pellets to deep carbon transport in the Scotia Sea (Southern Ocean). 933 Biogeosciences. 2015 Mar 25;12:1955-65.

934 117. Davison PC, Checkley DM, Koslow JA, Barlow J. Carbon export mediated by 935 mesopelagic fishes in the northeast Pacific Ocean. Progress in Oceanography. 2013 Sep $936 \quad 1 ; 116: 14-30$.

937 118. Giering SLC, Sanders R, Lampitt RS, Anderson TR, Tamburini C, Boutrif M, et al. 938 Reconciliation of the carbon budget in the ocean's twilight zone. Nature. 2014 939 Mar;507(7493):480-3.

940 119. Butterfield NJ. Plankton ecology and the Proterozoic-Phanerozoic transition. $941 \quad$ Paleobiology. 1997;23(2):247-62. 